\title{
In vitro effect of fungicides and phyto-extracts against Alternaria alternata causing leaf blight of groundnut
}

\author{
${ }^{1}$ S.L. Kantwa, ${ }^{2}$ J.P. Tetarwal* And ${ }^{3}$ K. S. Shekhawat \\ ${ }^{1,3}$ Department of Plant Pathology, S.K.N.College of Agriculture (SKRAU, Bikaner), Jobner (Rajasthan)-303328 \\ ${ }^{2}$ Department of Plant Pathology, Rajasthan College of Agriculture, MPUAT, Udaipur (Rajasthan)-313001
}

\begin{abstract}
Leaf blight caused by Alternaria alternata (Fr.) Keissler was observed on leaves of groundnut (Arachis hypogaea L.).The fungus was isolated from infected leaves and observed to be pathogenic under artificial inoculation conditions. Among plants extract, garlic clove extract was most effective in inhibiting the mycelial growth and sporulation of Alternaria alternata, followed by neem and datura leaf extracts. Babul leaf extract was not inhibiting the mycelial growth and sporulation of the fungus in poisoned food technique. Mancozeb at 1000 ppm resulted complete inhibition of mycelial growth and sporulation, followed by copper oxychloride and Captaf. Propiconazole was least effective followed by captan and chlorothalonil.
\end{abstract}

Key words: Alternaria alternata, Fungicides, Phy-extracts, Leaf blight, Groundnut

Groundnut (Arachis hypogaea.L) is mainly grown as an oilseed kharif crop in India, but considerable quantities are used directly for human consumption like other pulses. The kernels are widely acknowledged as a rich \&cheap source of vegetable protein. The chemical composition of the kernels indicating their value as food with: protein 25.33 , carbohydrates 10.20 , fat 40.50 , fibre 3.4 , \& ash 1.9 percent. A principal limiting factor in profitable cultivation of this crop in Rajasthan is the attack of several diseases mainly caused by fungi which cause heavy crop losses at all the stages, right from sowing to harvest and storage. The diseases which affect the foliage cause extensive damage to tissues involved in photosynthesis, and hence, result in yield losses. Leaf blight caused by Alernaria alernata is an important disease in the major groundnut growing areas of the state. The disease appears as small oval discolored lesions scattered irregularly on the leaves these spots become irregular in shape with increase in size and appear brown to grey in colour with yellow zone surrounding the spots. In the disease occurs widely in the crops grown in sandy soil in the Rajasthan, where weather conditions are dry, and temperature remains high. Under favourable conditions, spread of disease is rapid involving all the plants in a field and such blighted plants can be recognized from a distance. Keeping in view the importance of the disease, the present study was conducted during 2006-07 to evaluate in vitro efficacy of some phyto-extracts and systemic as well as non-systemic fungicides against Alternaria alternate

\section{Materials And Methods}

The effect of fungicides and plant extracts against mycelial growth and sporulation of Alternaria alternata was tested by poisoned food technique (Schimitz, 1930). Each fungicides and plant extracts were tested at five different concentrations viz; 50,100, 200, 500 and $1000 \mathrm{ppm}$. Plant part was thoroughly washed with sterilized water \& was grinded separately in electric grinder using equal amount of sterilized water to get stock solution. The extract thus obtained was considered as the 100 percent concentration. Each plate was inoculated with $2 \mathrm{~mm}$ disc of mycelial bit taken from the periphery of 7days old culture of Alternaria alternata growing on PDA. The inoculated Petri-plates were incubated at $25 \pm 2^{\circ} \mathrm{C}$. Four Petri-plates were used for each treatment serving as four replications. Petri-plates without fungicide and plant extract severed as control. The experiment was conducted in completely randomized design (CRD). Colony diameter was measured along the two diagonals passing through the colony by excluding initial diameter $(2 \mathrm{~mm})$ of bit, and sporulation by using Haemocytometer. Colony diameter and sporulation were measured after 7 days of incubation. Per cent growth inhibition was calculated by Vincent's (1947) formula follows:

$\mathrm{C}-\mathrm{T}$

Per cent growth inhibition $=---------\mathrm{x} 100$

$\mathrm{C}$

Where,

$\mathrm{C}=$ Diameter of the colony in check (average of both diagonals)

$\mathrm{T}=$ Diameter of colony in treatment (average of both diagonals) 
In vitro effect of fungicides and phyto-extracts against Alternaria alternata causing leaf blight ...

Following plant extracts were tested against Alternaria alternata

\begin{tabular}{llll}
\hline S.No. & Name of plant & Botanical name & Plant part used \\
\hline 1 & Babul & Acacia nilotica & Leaves \\
2 & Dhatura & Datura stramonium L. & Leaves \\
3 & Garlic & Allium sativum & Clove \\
4 & Ginger & Zingiber officinale Roscoe & Rhizome \\
5 & Jungly chouli & Amaranthus viridis & Leaves \\
6 & Neem & Azardirachta indica A. Juss & Kernel and leaves \\
7 & Tulsi & Ocimum sanctum & Leaves \\
\hline
\end{tabular}

Following fungicides were tested against Alternaria alternata.

\begin{tabular}{|c|c|c|c|c|}
\hline S.No & Common name & Trade name & Chemical name & \\
\hline 1 & Captaf & Difoltan & $\mathrm{N}(1,12,2$, tetrachloroenc-1-2-dicarboximide & \\
\hline 2 & Captan & Captan $50 \mathrm{WP}$ & $\mathrm{N}$-trichloromethl thiomethoxam 4 cyclo & \\
\hline 3 & Carbendazim & Bavistin & Methyl-1,2,benzimidazole carbamate & \\
\hline 4 & Chlorothalonil & Kavach 75 WP & Tetrachloraiso-phthalonitrile & \\
\hline 5 & Copper oxychloride & Blitox 50 & Dicoper chloride trihy droxide & \\
\hline 6 & Mancozeb & Indofil M-45 & Hexane-1, 2 dicarboximide & \\
\hline 7 & Propiconazole & Tilt & $\begin{array}{l}\text { 1-12-(2-4-dichlorophenyl)- } \\
\text { ylmethyll- } 1 \mathrm{H}-1,2, \text { 4-triazole }\end{array}$ & dioxalan-2- \\
\hline
\end{tabular}

\section{Results \& Discussion}

Effect of plant extracts on mycelial growth and sporulation of Alternaria alternata

Efficacy of seven plant extracts, each at five concentrations (50,100, 200, 500 and $1000 \mathrm{ppm})$, was tested against the mycelial growth and sporulation of Alternaria alternata. Irrespective or the concentration, garlic clove extract was found most effective in inhibiting the mycelial growth $(46.60 \%)$ of A. alternata followed by neem $(43.30 \%)$ and datura $(40.30 \%)$ leaf extract. Babul and jungly chouli leaf extracts were least effective in inhibiting the mycelial growth of A. alternata. Singh and majumdar (2001) reported that Allium sativum, Azardirachta indica A. Juss, Datura stramonium L. and Ocimum sanctum were found most effective against A. alternata. Plant extract of neem was found to be most effective against A. alternata causing leaf blight of groundnut (Nandagopal and Ghewande, 2004). Garlic resulted in minimum sporulation $\left(7.60 \times 10^{6}\right)$, compared to neem $\left(10.50 \times 10^{6}\right)$ and datura $\left(12.35 \times 10^{6}\right)$. Maximum sporulation of A. alternata was recorded with babul $\left(17.50 \times 10^{6}\right)$, compared to jungly chouli $\left(15.50 \times 10^{6}\right)$ and ginger $\left(14.40 \times 10^{6}\right)$.

\section{Effect of fungicides against mycelial growth and sporulation of A. alternate}

Mancozeb proved to be the most effective fungicide in inhibiting the mycelial growth of Alternaria alternata $(75.46 \%)$ followed by copper-oxychloride $(71.95 \%)$ and captafol $(65.20 \%)$. Propiconazole was least effective in inhibiting the mycelial growth of the fungus, followed by chlorothalonil and captan. Mancozeb at $1000 \mathrm{ppm}$ gave maximum growth inhibition (100.00\%) followed by copper-oxychloride at $1000 \mathrm{ppm}(95.20 \%)$ and mancozeb $500 \mathrm{ppm}(90.50 \%)$. Minimum inhibition was recorded in propiconazole at $50 \mathrm{ppm}(8.42 \%)$ followed by captan $(15.50 \%)$ and chlorothalonil. Krishna et al (1998) reported that mancozeb completely inhibited growth of Aalternata spp. followed by copper-oxychloride and carbendazim. Ghosh et al (2002) also reported that mancozeb was most effective against in vitro mycelial growth and sporulatian of A. alternata. Mancozeb gave minimum sporulation $\left(5.20 \times 10^{6}\right)$, compared to copper-oxychloride $\left(7.05 \times 10^{6}\right)$ and captafol $\left(7.87 \times 10^{6}\right)$. Maximum sporulation of Alternaria alternata was recorded with propiconazole $\left(14.20 \times 10^{6}\right)$, compared to captan $\left(13.05 \times 10^{6}\right)$ and chlorothalonil $\left(12.50 \times 10^{6}\right)$. Lowest $\left(0.00 \times 10^{6}\right)$ sporulation of Alternaria alternata was observed with mancozeb (1000 ppm) compared to $500 \mathrm{ppm}$ of mancozeb $\left(3.25 \times 10^{6}\right)$ and 1000 ppm copper-oxychloride $\left(4.00 \times 10^{6}\right)$. Maximum sporulation $\left(18.00 \times 10^{6}\right)$ was observed with propiconazole 50 ppm, compared to captan $50 \mathrm{ppm}\left(17.00 \times 10^{6}\right)$ and chlorothalonil $50 \mathrm{ppm}\left(16.50 \times 10^{6}\right)$. However, captan 50 $\mathrm{ppm}$ and propiconazole $1000 \mathrm{ppm}$ were at par in reducing the sporulation at $5 \%$ level of significance.

\section{References}

[1]. Ghosh, C.; Pawar, N.B.; Kshirsagar, C.R. and Jadhav, A.C. 2002. Studies on management of leaf spot caused by Alternaria alternata on gerbera. J. Maharastra Agril. Univ. 27: 165-167.

[2]. Krishna, K.; Akbar, A.F.M.; Sastry, R.K.; Reddy, T.V. and Gour, T.B. 1998. In vitro evaluation of fungicides against Alternaria carthami Chowdury incitant of leaf spot of safflower. Indian J. Pl. Protec. 26 (2) : 181-182.

[3]. Nandagopal, V. and Ghewande, M.P. 2004. Use of neem products in groundnut pest management in India. Natural Product Radiance. 3 (3) : 150-155.

[4]. Schimitz, H. 1930. A suggested toximetric method for wood preservation. Indus Engia. Chem. Analyt. Ed. 2: $361-363$.

[5]. Singh, J. and Majumdar, V.L. 2001. Efficacy of plant extracts against Alternaria alternata - the incitant of fruit rot of pomegranate (Punica granatum L.). J. Mycol. Pl. Path. 31 : 346-349.

[6]. Vincent, J.M. 1947. The esters of 4-hydroxy benzoic acid and related compounds, I. Methods for the study of their fungistatic properties. J. Soc. Chem. Ind. Landan. 16: 746-755. 
In vitro effect of fungicides and phyto-extracts against Alternaria alternata causing leaf blight ...

Table 1- In vitro efficacy of phytoextracts against mycelial growth of Alternaria alternata

\begin{tabular}{|c|c|c|c|c|c|c|c|}
\hline \multirow[t]{2}{*}{ S. No. } & \multirow[t]{2}{*}{ Name of plant } & \multicolumn{5}{|c|}{ Per cent inhibition of mycelial growth concentration in ppm* } & \multirow{2}{*}{ Mean } \\
\hline & & 50 & 100 & 200 & 500 & 1000 & \\
\hline \multirow[t]{2}{*}{1.} & Babul & 21.75 & 25.00 & 27.25 & 30.50 & 35.75 & 28.05 \\
\hline & & $(27.79)$ & $(30.00)$ & $(31.46)$ & $(33.52)$ & $(36.72)$ & $(31.97)$ \\
\hline \multirow[t]{2}{*}{2.} & Datura & 28.00 & 35.25 & 38.75 & 42.25 & 57.50 & 40.35 \\
\hline & & (31.94) & $(36.42)$ & (38.49) & (40.54) & (49.31) & (39.43) \\
\hline \multirow[t]{2}{*}{3.} & Jangly choulia & 25.50 & 27.75 & 31.25 & 35.50 & 39.25 & 31.85 \\
\hline & & (30.32) & (31.78) & (33.98) & (36.57) & (38.79) & (34.35) \\
\hline \multirow[t]{2}{*}{4.} & Garlic & 36.25 & 39.75 & 42.50 & 49.75 & 64.75 & 46.60 \\
\hline & & (37.01) & (39.08) & (40.68) & $(44.85)$ & (53.57) & $(43.05)$ \\
\hline \multirow[t]{2}{*}{5.} & Ginger & 26.75 & 31.00 & 34.40 & 38.00 & 42.25 & 34.48 \\
\hline & & (31.14) & (33.83) & (35.91) & (38.05) & (40.54) & (35.95) \\
\hline \multirow[t]{2}{*}{6.} & Neem & 29.75 & 36.50 & 41.00 & 46.50 & 62.75 & 43.30 \\
\hline & & (33.05) & (37.16) & (39.81) & (42.99) & $(52.38)$ & (41.14) \\
\hline \multirow[t]{2}{*}{7.} & Tulsi & 27.25 & 32.75 & 35.50 & 39.00 & 44.75 & 35.85 \\
\hline & & (31.46) & (34.90) & (36.57) & (38.64) & (41.98) & (36.78) \\
\hline \multirow[t]{8}{*}{8.} & Check & 0.00 & 0.00 & 0.00 & 0.00 & 0.00 & 0.00 \\
\hline & & $(0.00)$ & $(0.00)$ & $(0.00)$ & $(0.00)$ & $(0.00)$ & $(0.00)$ \\
\hline & Mean & 24.40 & 28.49 & 31.33 & 35.18 & 43.37 & \\
\hline & & (29.60) & $(32.25)$ & (34.04) & (36.37) & (41.19) & \\
\hline & & \multicolumn{2}{|c|}{ SEm \pm} & \multicolumn{3}{|c|}{ C.D. at $5 \%$} & \\
\hline & Plant extract (E) & \multicolumn{2}{|c|}{$0.40^{-}$} & \multicolumn{3}{|c|}{1.13} & \\
\hline & Concentration $(\mathrm{C})$ & \multicolumn{2}{|c|}{0.30} & \multicolumn{3}{|c|}{0.86} & \\
\hline & $\mathrm{E} \times \mathrm{C}$ & \multicolumn{2}{|c|}{0.93} & \multicolumn{3}{|c|}{2.63} & \\
\hline
\end{tabular}

* Average of four replications

Figures given in parenthesis are angular transformed values

Table 2-In vitro efficacy of phytoextracts against sporulation of Alternaria alternata

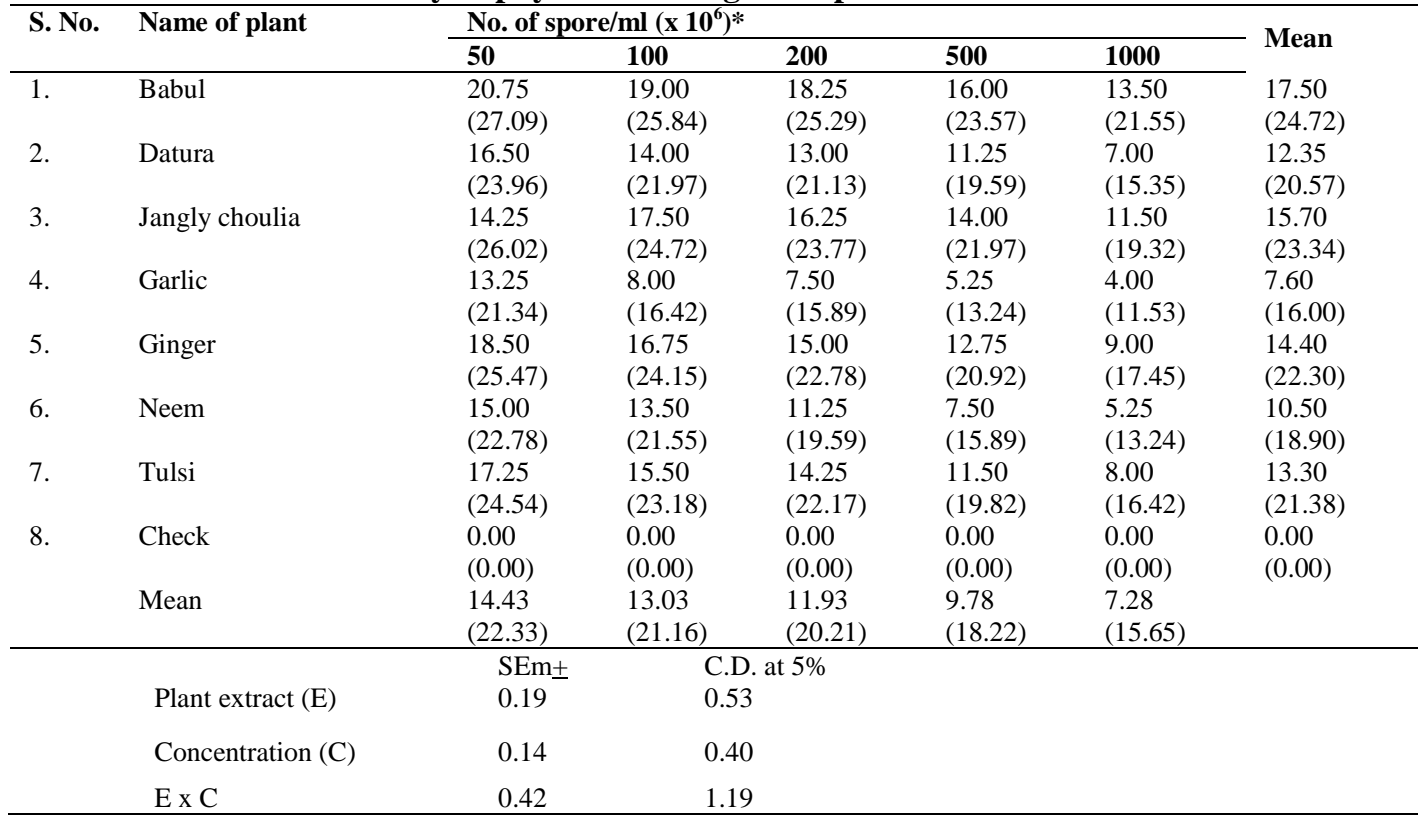

* Average of four replications

Figures given in parenthesis are angular transformed values 
In vitro effect of fungicides and phyto-extracts against Alternaria alternata causing leaf blight ...

Table 3- In vitro efficacy of fungicides against mycelial growth of Alternaria alternata

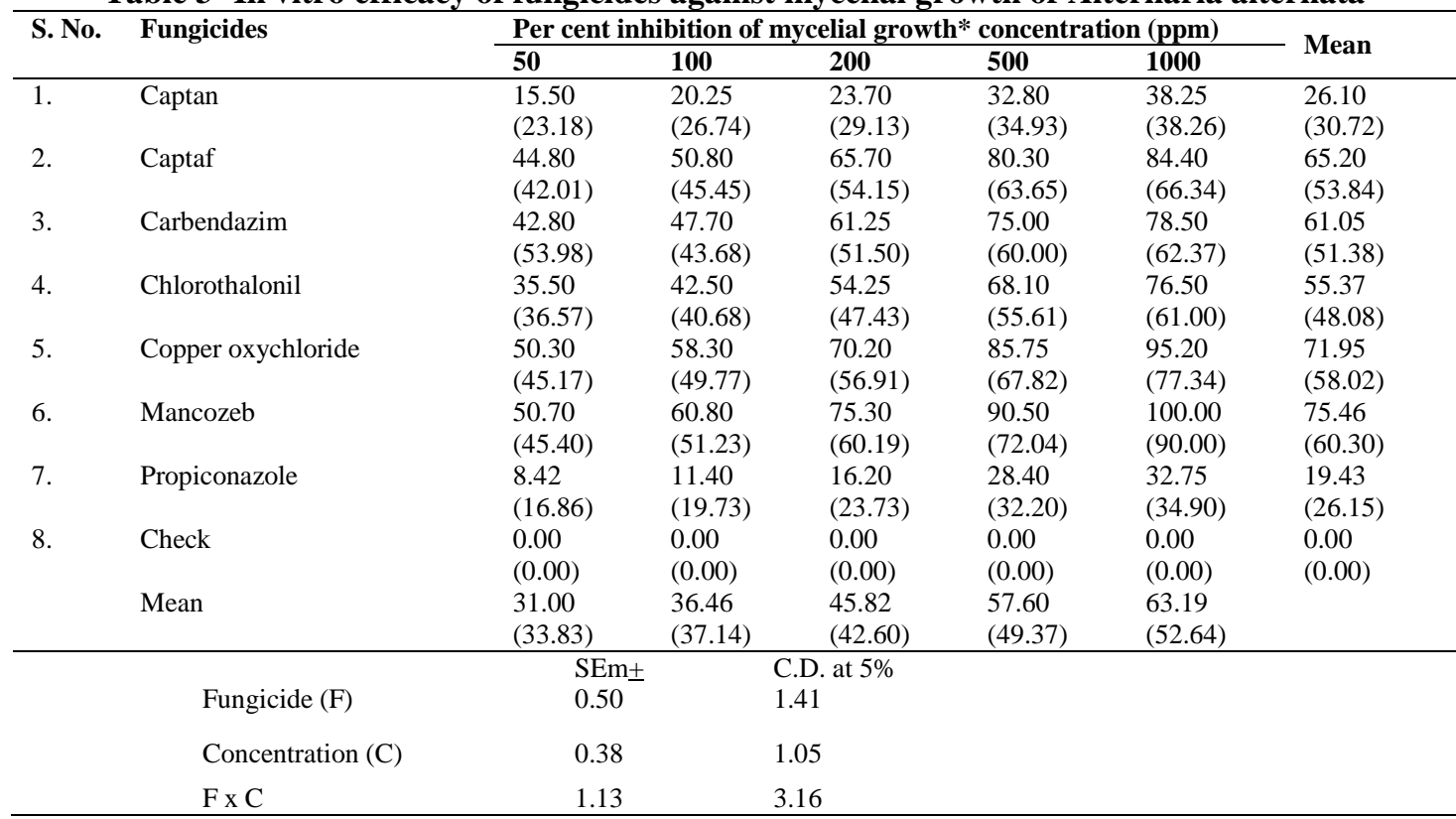

* Average of four replications

Figures given in parenthesis are angular transformed values

Table 4- In vitro efficacy of fungicides against sporulation of Alternaria alternata

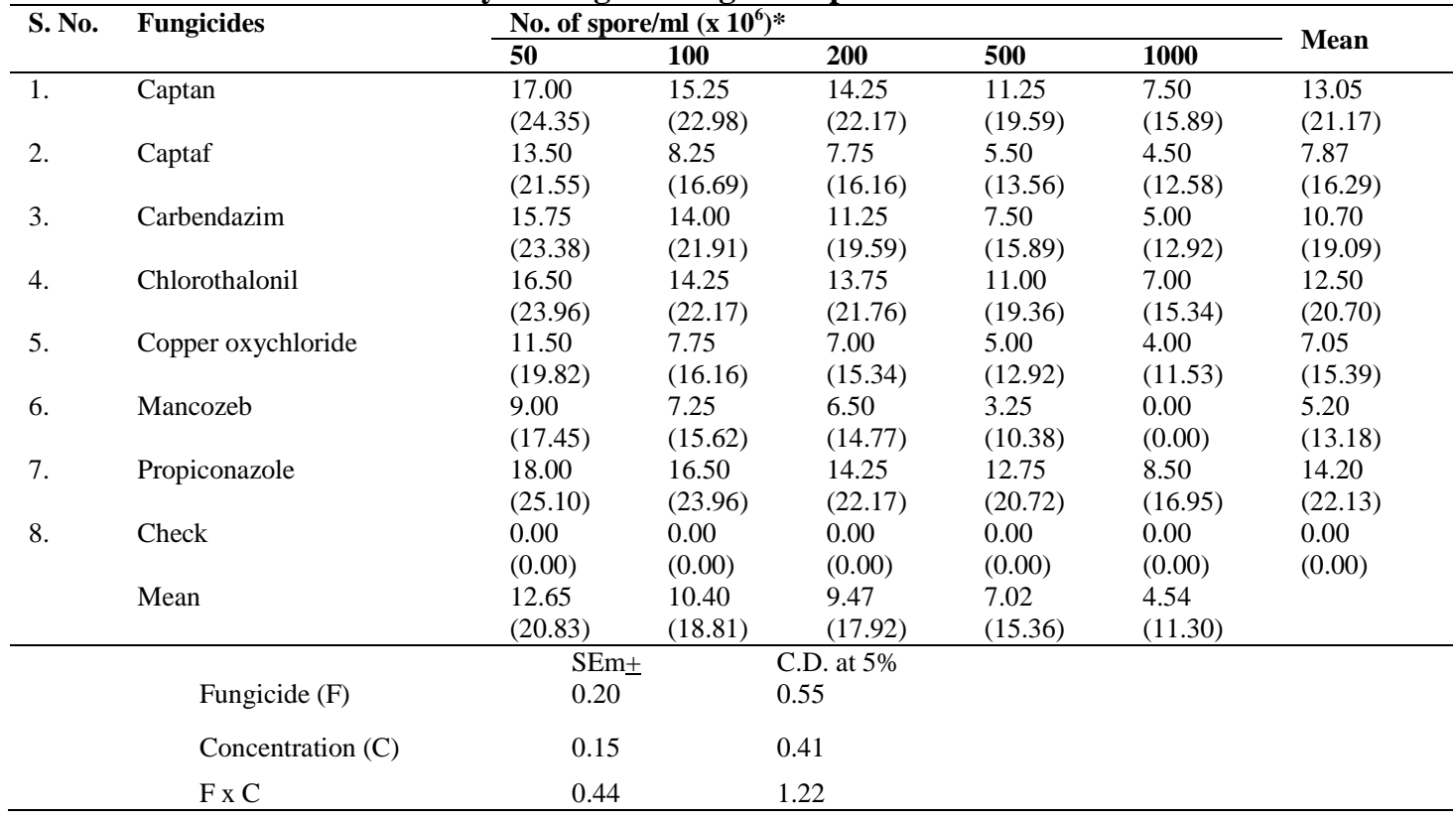

* Average of four replications

Figures given in parenthesis are angular transformed values 